\title{
Trends in primary school teachers' experience over the first year of the COVID-19 pandemic in Serbia: A narrative analysis
}

\section{Katarina Mićić ${ }^{1}$}

Department of Psychology, Faculty of Philosophy, University of Belgrade

\section{Tünde Kovács Cerović}

Department of Psychology, Faculty of Philosophy, University of Belgrade

\section{Selena Vračar}

Department of Psychology, Faculty of Philosophy, University of Belgrade

\begin{abstract}
The purpose of the study is to explore the experiences shared by primary school teachers in three waves of data collection. Teachers' narratives about their experiences of schooling during the COVID-19 pandemic were elicited online. In three instances, a total of 116 participants were prompted to narrate in story and letter genres, providing 233 narratives. We conducted the values analysis and additionally analysed data statistically in order to compare the values teachers expressed at three key turning points for education in the first year of the COVID-19 pandemic in Serbia. Altogether, three major values and nine value codes were identified. This multi-genre three-wave approach provided a nuanced and comprehensive picture of teachers' most important impressions, concerns, and strategies in the new reality, in particular as the emphasis changed over the course of one year of the pandemic. Teachers who took part in the first wave mostly focused on health and prevention issues, their duties, the workload, and the strategies for coping with the new normal. In the second wave, as the threat eased, teachers expressed increased awareness of schooling related issues. Teachers' narratives in the third wave primarily focused on the learning process and outcomes. Based on the conducted analyses, the paper draws policy recommendations.
\end{abstract}

Keywords: COVID-19, distance education, teachers, value analysis, dynamic storytelling

1 katarina607@gmail.com 


\section{Introduction}

The sudden, uncalled-for, and rapid shift to distance schooling due to the outbreak of COVID-19 pandemic was one of the greatest challenges for the education systems worldwide in recent history. Countries had to find ways to sustain education, devise procedures, set up structures, and organise instruction. Everything which, up to that point, had been perceived as $a$ matter of fact became a matter of concern (Alacron Lopez et al., 2021). In this endeavour, reliance on technology and the Internet was the most commonly used solution worldwide. ${ }^{2}$ Although previous strivings towards digitalisation of education (see McFarlane, 2019) made this transition somewhat easier, governments, schools, teachers, students, and parents were forced to change their entrenched routines overnight and adopt digitally mediated practices. Teachers, as the carriers of the educational process, were perhaps more affected by this transition and in more complex ways than other stakeholders, especially those working with younger students and students transiting from class to subject instruction. This paper aims to explore the ways in which teachers narrate about their experiences during this period, as well as the ways in which they made sense of these experiences and conveyed their stances using different narrative genres.

The novel context of education, with profusion of the unknown, rapidly mobilized the research community to investigate the manifold features of the new kind of schooling and support policy makers and practitioners with recommendations based on scientific evidence. To find our research niche and provide a snapshot of the already rich production of publications, we conducted a review of the published papers. By using ERIC, ScienceDirect, and SAGE pub engines, we found over 400 distinct articles from peerreviewed journals published between June 2020 and June 2021. The search was conducted by using keywords: abstract:(“COVID 19" OR "pandemic" OR "coronavirus") AND ("online education" OR "distance education" OR "distance learning" OR "school closure" OR "school closing")), and narrowing the search further to Education and Science and Humanities fields. The mushrooming of publications went hand in hand with the proliferation of terminology used to refer to the new ways of schooling during the pandemic. Usually, distance education and remote education are used to stress that teachers and students are physically apart (e.g., in Lepp et al., 2021); online education is used for emphasising the medium for teaching/learning (e.g., in MacIntyre et al., 2020), and blended or hybrid learning for models of schooling where classes are conducted by a combination of online and inperson instruction (e.g., in Tabor \& Smith, 2020). Since these models existed pre-pandemic, some authors use the term emergency remote education to

2 https://en.unesco.org/covid19/educationresponse/nationalresponses 
highlight its specificities (e.g., in Toquero, 2020). In this article, besides the above listed, we also use a descriptive phase schooling during the pandemic as an overarching term when needed.

We reviewed open-access empirical studies (156 total) in order to assess the prevalence of those building on teachers' experiences. The majority focused on higher education students and staff (54\%), with only a small portion (12\%) focusing on primary and lower secondary education and including samples of teachers. Teachers' views still seem underrepresented. Despite the abundance of new research, their professional experiences, opinions, and suggestions during the pandemic have not been explored in sufficient detail to become influential and relevant for policy-makers. Figure 1 shows the stepwise approach used during the literature search that led us to the niche of our interest, where only 11 qualitative studies addressing the emergency remote education-related experiences of primary and lower secondary teachers were found.

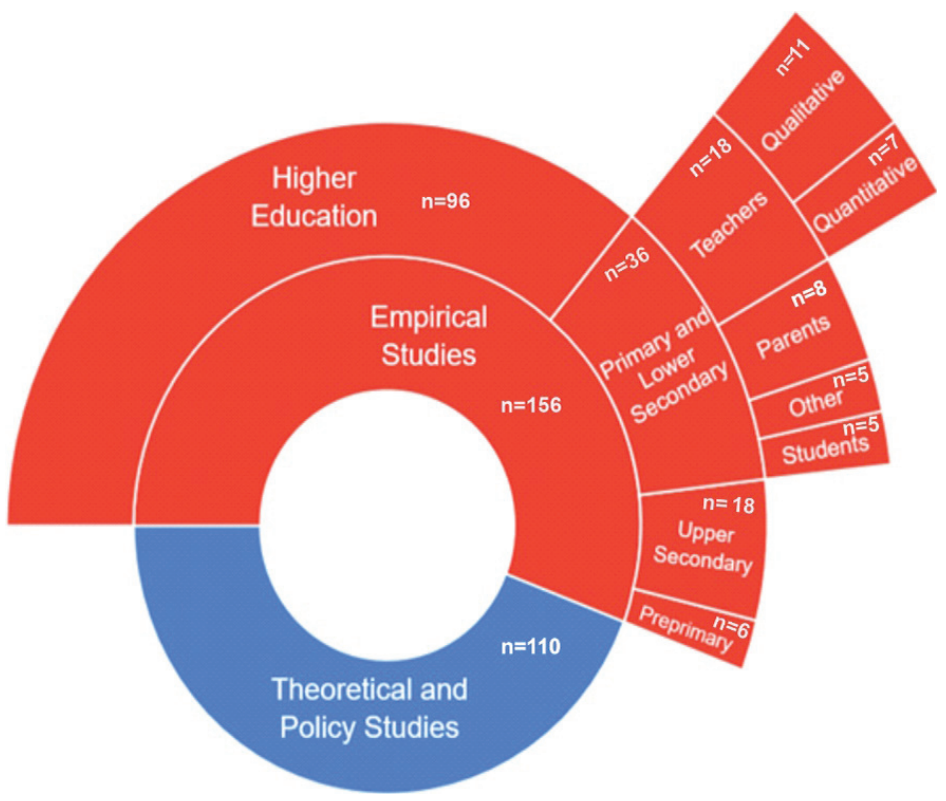

Figure 1. The share of different types of articles on schooling during the pandemic

Out of these 11 studies exploring teachers' experiences, eight were conducted at the beginning of the pandemic, capturing the first reactions and thoughts, one study captured the beginning of the 2020/21 academic year, while the remaining two did not provide information about the data collection period. 
Primary and secondary school teachers faced many challenges during the pandemic, as shown in both qualitative and quantitative studies. Findings from very different geographic areas ${ }^{3}$ were often quite similar, suggesting that some aspects of teachers' experiences played out universally across different contexts.

Reaching out to students with no access to the digital environment was reported as one of the biggest challenges teachers faced (Frohn, 2021). A commonly reported obstacle was the absence of in-person interaction, causing non-authentic communication and a lack of spontaneity (Niemi \& Kousa, 2020), the absence of instant feedback on students' participation, and a lack of social interactions, which is why teachers frequently opted for lecturing via video calls (Lepp et al., 2021). Another concern was maintaining students' learning motivation and engagement during online schooling (Chiu et al., 2021). Studies have shown that to get students present and interested, teachers used different platforms, prepared diverse assignments to meet different preferences, and provided individual feedback (Lepp et al., 2021; Wicaksana et al., 2021).

Studies focusing on teachers' mental health reported that their initial reactions included a sense of rush, panic (Kim et al., 2021), anxiety related to change, and higher levels of stress (Collie, 2021). A serious source of stress was the increased workload (Kaden, 2020; Kraft \& Simon, 2020). More demanding work was the feature of schooling during the pandemic often reported by both students (Kovács Cerović et al., 2021; Pelikan et al., 2021) and teachers (Kaden, 2020; Kraft \& Simon, 2020). Teachers' workload expanded due to the time-consuming preparation of digital materials and setting up platforms for extensive communication with parents (See et al., 2020). Heavier workload was also reported by teachers who had to teach both online and in-person due to different communication needs of students (Kaden, 2020), thus doubling the amount of work (Collie, 2021). In addition to expanding the professional obligations of teachers, the pandemic brought about an increase in the amount of their home-related activities, such as housework, childcare, and homeschooling their own children (See et al, 2020). Studies also suggested that the two roles were often conflicting, causing additional stress (Kara et al., 2021).

Studies also looked into teachers' coping strategies. MacIntyre et al. (2020) found that the most frequently used coping strategies of teachers were acceptance, advanced planning, re-framing, and being proactive about the situation. Lepp et al. (2021) found that the teachers' concern with students' and their own workload and wellbeing often led to reducing the

3 The presented findings are from studies conducted mainly in the European, North American, and Asian countries. 
amount of content, postponing more complex topics, and not going into depth.

However, we did not detect the studies comparing different periods or different schooling models during the pandemic, albeit education contexts worldwide had been changing swiftly in response to the changing health situation. In Serbia only, where our study was conducted, the organisation of schooling switched several times during the year. From school closure in mid-March until July 2020, schooling was organised remotely, as distance learning (most frequently via live-streaming lectures and by uploading materials to learning platforms or social media groups), coupled with TV lessons. The academic 2020/2021 year began with hybrid-model classes, a combination of in-school classes (that students attended in shifts or on alternate days/weeks) and distance learning. In March 2021, due to the exacerbation of the epidemiological situation, classes were again switched to distance learning exclusively (Government of the Republic of Serbia, 2020a,b,c, 2021).

\section{Methodology: a multi-wave and multi-genre approach}

The study aims to contribute to filling the research gaps in the emerging literature about education during the pandemic in two important directions. It explores the dynamics of teachers' experiences as being immersed in the year(s) long pandemic crisis, delineating the ways teachers made sense of the changing context and their role in it. The study presents periodic snapshots corresponding to three different emergency schooling contexts in Serbia, between March 2020 and April 2021 - hence the multi-wave slant. The study also introduces a novel, theory-based, narrative approach, dynamic storytelling (Daiute, 2008; 2013). It builds on the understanding that narrating is a cultural tool that people purposefully use in active ways (Bruner, 1987) to figure out what is going on around them, how they fit and how to change what surrounds them (Parker, 2004; Daiute \& Nelson, 1997) - which is indispensable in times of crisis. The approach has emerged from more than 20 years of research underpinning the understanding of discourse processes as relational activities expressed through diverse genres - stories, letters, requests, etc. (Daiute, 2010; 2014; Bamberg 2004; Georgopoulou, 2006), which have a potential to interact with policy and power structures (Daiute \& Kovač-Cerović, 2017). Therefore, teachers who faced a sudden and unwanted change of their role enactments and teaching routines, accompanied by uncertainties of the pandemic, were in all three waves invited to share their narrative expressions in two genres - stories and letters, thus allowing for a time-genre study design. The story genre 
called for an exploration of the events, feelings, and people involved, while the letter genre allowed for an intentional selection of relevant experiences to be shared. Previous studies show that this methodology facilitates the expression of nuanced views and hard-to-access areas of emergent experiences (Daiute \& Kovač-Cerović, 2017; Daiute et al., 2020; KovácsCerović et al., 2021; Jović, 2020; Daiute, 2021).

The research questions guiding this multi-wave and multi-genre study were the following: What are the experiences of teachers about education in the pandemic they chose to share through narrative expressions? Do teachers' experiences differ across time and across genres and in which way?

\section{Sample of participants and narratives}

Three subsamples with a total of 116 subject teachers from 18 primary 4 schools across Serbia produced 223 narratives (Table 1). Responses were collected in three waves following the key turning points in Serbian education during the pandemic: the first lockdown and the first comprehensive transition to online schooling (May and June 2020); the end of autumn 2020/21 semester, when most schools switched to the hybrid model (December 2020); and the second lockdown and re-transition to exclusively online schooling (April 2021).

Table 1

Sample of teachers and their narratives by genre, per wave

\begin{tabular}{|c|c|c|c|c|}
\hline \multirow{2}{*}{ Wave } & \multirow{2}{*}{ Teachers } & \multicolumn{3}{|c|}{ Narratives } \\
\hline & & Stories & Letters & Total \\
\hline & $\mathrm{N}=31$ & & & \\
\hline Wave 1 & $\begin{array}{l}88 \% \text { females } \\
47 \% \text { from rural schools } \\
\text { AVG work experience }=16.1\end{array}$ & 28 & 31 & 59 \\
\hline & $\mathrm{N}=58$ & & & \\
\hline Wave 2 & $\begin{array}{l}89 \% \text { females } \\
52 \% \text { from rural schools }\end{array}$ & 57 & 57 & 114 \\
\hline & AVG work experience $=15.5$ & & & \\
\hline & $\mathrm{N}=27$ & & & \\
\hline Wave 3 & $\begin{array}{l}81 \% \text { females } \\
42 \% \text { from rural schools } \\
\text { AVG work experience }=15.3\end{array}$ & 23 & 27 & 50 \\
\hline Total & 116 & 108 & 115 & 223 \\
\hline
\end{tabular}

4 In Serbia, this encompasses grades 1-8. 


\section{Instrument}

An online instrument was used, consisting of prompts designed to elicit narration in accordance with the dynamic storytelling approach (Daiute \& Kovač-Cerović, 2017). For the story genre, the prompt was: Please write a story about schooling during the pandemic and reflect on your experiences in the current school year. You can write about how you manage the teaching, your view of the teaching process in your school, and the things you would change; the prompt for the letter was: Imagine you are writing a letter to a colleague whose school is about to change the teaching model due to the pandemic. What would you warn them about, what advice would you give them? Google Forms links to the instrument were distributed to the participants via school management.

\section{Analysis}

Firstly, 223 narratives were parsed into thought units (usually one unit per sentence), resulting in a total of 1,389 units. Each of these units was coded with attention to its expressive intent as required by values analysis (Daiute, 2013), thoroughly described elsewhere (Kovács Cerović et al., 2021). A statistical analysis ensued. For the majority of the analyses, the data were aggregated across genres on the level of a participant. To mitigate the effect of differing lengths of the narratives (determined by causes irrelevant for this occasion, such as motivation for participation), the analyses were conducted on binarised data, registering the presence or absence of each value in each participant's narration. In addition to descriptive statistics, we used the Chisquare test to check for differences in the share of teachers expressing each value in the three waves and between genres.

\section{Results}

Nine recurrent values, gravitating towards three major values (Figure 2 ), organise teachers' narratives, albeit in somewhat different ways across waves. The results for each major value across three data collection waves are presented first, rounded up by the summing-up of the overall results. Although our sample does not allow for the conclusions about the change of expressive focus by individual teachers across time, the observed differences of expressions across the waves indicate contextually meaningful changes of experiences, possibly shared by many teachers. 

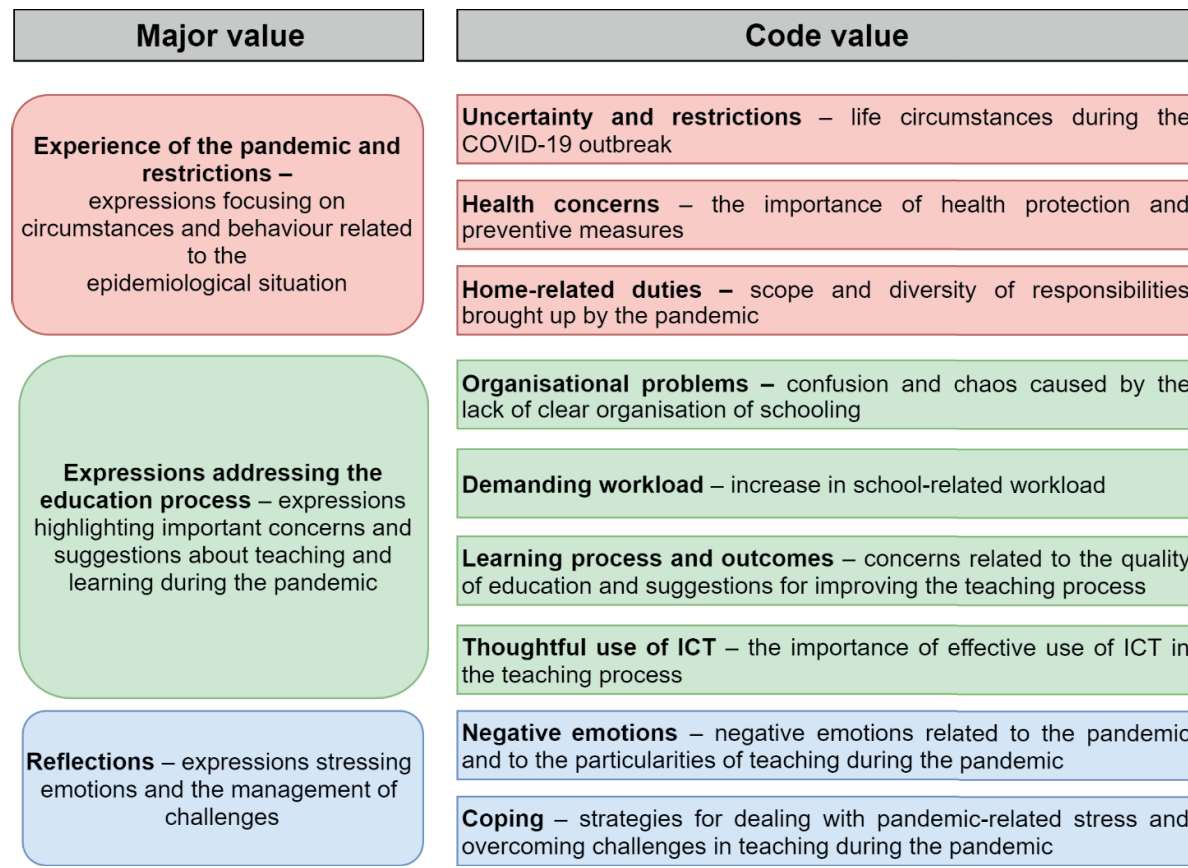

Organisational problems - confusion and chaos caused by the lack of clear organisation of schooling

Demanding workload - increase in school-related workload

Learning process and outcomes - concerns related to the quality of education and suggestions for improving the teaching process

Thoughtful use of ICT - the importance of effective use of ICT in the teaching process

Negative emotions - negative emotions related to the pandemic and to the particularities of teaching during the pandemic

Coping - strategies for dealing with pandemic-related stress and overcoming challenges in teaching during the pandemic

Figure 2. The values organising teachers' narratives

\section{Experience of the pandemic and restrictions}

Mentions of the pandemic and restrictions in teachers' narratives decreased over time, as shown in Figure 3. In the first wave, 33\% of teachers made references to uncertainty and restrictions, addressing the accompanying fears and unease ("Fear of the unknown is present, pictures from around the world are discouraging."; "I would advise them [other teachers] to prepare themselves [for the lockdown], especially if they live in apartments."). Similarly, $40 \%$ of them emphasized health concerns, writing about the importance of implementing epidemiological measures ("They should not attend large gatherings."; "It is important they pay attention to hygiene."). Many (50\%) complained about the additional home-related duties caused by restrictions ("In the morning, I have to queue to buy 5-6 loaves of bread for my family, my parents in their 80s, and my neighbour living alone with two small children."; "A quick shopping for groceries for my family and my retired parents, and then an express delivery so that I can return home before the curfew."), and their new roles in home-schooling their children ("Along with everything else, I had to monitor schoolwork of my fourth-grade daughter and my third-grade son."; "I help my children with more demanding homework."). 
Over time, these expressions became less salient. All three values: uncertainty and restrictions, health concerns, and home-related duties were referred to by a significantly smaller share of the second-wave teachers $\left(X^{2}\right.$ $(1, N=88)=7.02, p=.008 ; X^{2}(1, N=88)=19.28, p=.000 ; X^{2}(1, N=88)=$ $14.57, p=.000$, respectively), which remained unchanged in the third wave $\left(X^{2}(1, N=85)=3, p=.083 ; X^{2}(1, N=85)=.34, p=.560 ; X^{2}(1, N=85)\right.$ $=2.47, p=.116$, respectively).

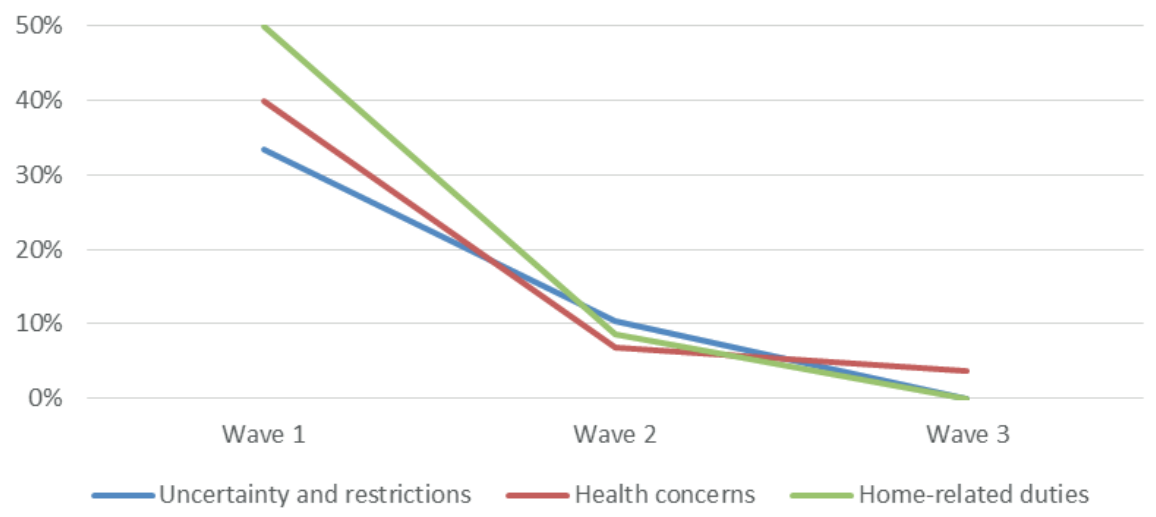

Figure 3. Experience of the pandemic and restrictions

\section{Expressions addressing the education process}

Teachers' narratives of the education process were guided by four values and their trends are shown in Figure 4. One of these values, organisational problems, featured in the narratives of $30 \%$ of the first-wave teachers. Teachers pointed to a lack of clear schooling procedures causing confusion and chaos ("You receive many different, even contradictory instructions within one week."; "In a heap of questions, dilemmas, complaints, and workaround suggestions, you eventually find a few messages that tell you what to do.").

The share of the second-wave teachers who mentioned organisational problems non-significantly dropped $\left(X^{2}(1, N=88)=1.37, p=.242\right)$, while the content of teachers' complaints remained similar.

In the third-wave sample, only a few teachers narrated about organisational problems. The drop was significant only in comparison to the first-wave sample $\left(X^{2}(1, N=57)=6.79, p=.009\right)$.

Teachers' narration very often pointed to a demanding workload - it occurred in the narratives of $50 \%$ of the first-wave teachers. They stressed an increase in the amount of professional obligations ("It means hours spent 
in front of a computer screen, reading and correcting students' homework and making notes."; "Writing reports and plans until late at night."), overwhelming communication with students, colleagues, and parents ("In 20 minutes I received 56 Viber messages, 15 Skype messages, 10 on Google Classroom, six e-mails, and three Messenger messages."; "One is constantly distracted by a surge of Viber messages.").

There was no significant change in the share of the second-wave $\left(X^{2}\right.$ $(1, N=88)=.21, p=.645)$ and the third-wave teachers $\left(X^{2}(1, N=87)\right.$ $\left.=.46, p=.499 ; X^{2}(1, N=57)=.97, p=.325\right)$ who addressed the demanding workload. Teachers still reflected on the exhausting communication, but also on tiresome work in the digital environment ("Online teaching is highly demanding and requires extensive preparation."; "Teaching via Google Classroom is much harder because we have to prepare all the materials.").

Figure 4 shows that the share of teachers who expressed concerns about the learning process and outcomes increased over the three sampling points during the year. These concerns were mentioned by only $20 \%$ of the firstwave teachers, mostly emphasising the importance of enhancing students' motivation and adjusting learning activities to their needs ("It is important to choose the most appropriate platform for all the students."; "I do everything to engage children and keep their motivation high.").

Among the second-wave teachers, 52\% were concerned with students' learning and outcomes, which is a significant increase $\left(X^{2}(1, N=88)=\right.$ $8.23, p=.004)$. Teachers' narratives also became more elaborate and diverse. They questioned the quality of online instruction ("I don't think this online work will do children any good, no matter which platforms we use."; "In my opinion, this cannot be a substitute for teaching in classroom."), stressed the lack of in-person communication as an important barrier ("No matter how hard we try, send materials, ask for feedback, nothing can compensate for the lack of live conversation in the classroom."), and commented on students' lack of motivation for learning ("Only several of them are genuinely interested, present at all times, doing homework, asking questions, participating, but this is a small portion of students."). Some teachers called for an improvement of the teaching process ("We should try to teach them the essence of the lesson."; "My colleagues should carefully choose the proper teaching methodology, try different approaches, and see how the class reacts.").

The share of teachers who were reflecting on the learning process and outcomes continued to grow in the third wave. Significantly more teachers, $81 \%$, addressed this value, as compared to the second wave $\left(X^{2}(1, N=85)\right.$ $=6.87, p=.009)$ or the first wave $\left(X^{2}(1, N=88)=21.49, p=.000\right)$. They mostly focused on the ways to ensure the quality of teaching ("One has to pay attention to the dynamics of a lesson so that the students don't fall asleep."; "Prepare problem-based tasks, grade them, and praise your students."). 
Thoughtful use of ICT was mentioned by teachers as a strategy for maintaining the quality of teaching during the pandemic in an online environment. However, as Figure 4 shows, this value was rarely expressed prior to the second wave, when the share of teachers focusing on it grew significantly $\left(X^{2}(1, N=88)=8.16, p=.004\right)$, reaching $34 \%$. In this wave, teachers felt that video calls could compensate for the lack of in-person contact ("Video calls are useful since they facilitate lesson-learning."; "Prepare presentations - oral communication is crucial in our work!"), and that online platforms provided a better overview of and permanent access to learning materials ("Content organisation is much easier, everything is in one place"; "All the content I made for my students is always available."). Some teachers described the way they used digital tools in teaching ("Work in Google classroom is a good way to individualize teaching"; "Different applications and quizzes are useful for the improvement of the teaching process.") and encouraged their colleagues to use them as well ("Start exploring the possibilities of online teaching."; "YouTube offers a lot of helpful material.").

The share of the third-wave teachers addressing the meaningful use of ICT remained similar $\left(X^{2}(1, N=85)=.011 p=.917\right)$ and stayed higher than in the first-wave sample $\left(X^{2}(1, N=57)=6.49, p=.011\right)$. Almost all ICT references in the third wave encouraged the use of video calls in teaching.

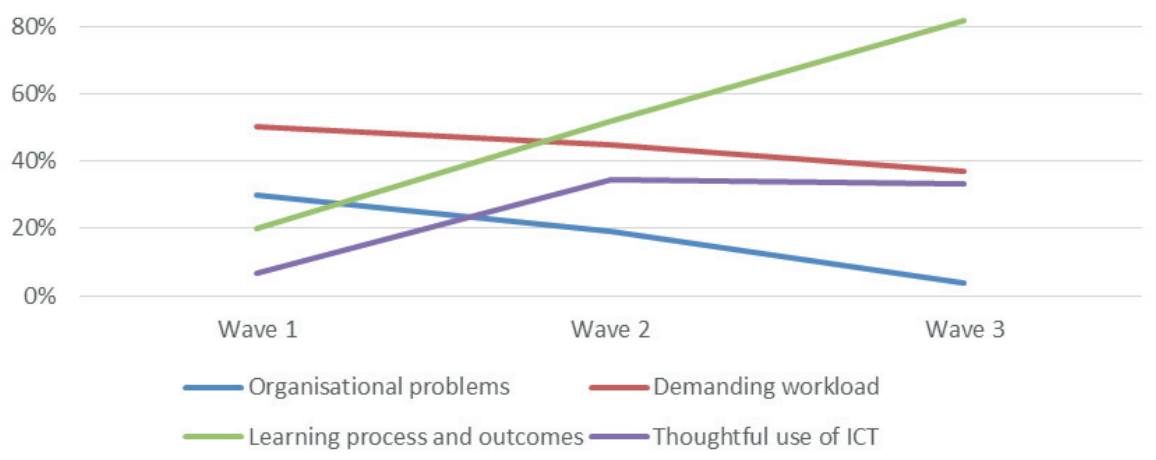

Figure 4. Perception of the schooling process

\section{Reflections}

Teachers reflected on their internal state and on teaching during the pandemic. As Figure 5 shows, 13\% of the first-wave teachers mentioned negative emotions such as pandemic-induced stress and anxiety ("The onset of the pandemic was quite stressful."; "You start to panic, but must hold on."). 
A similar share of the second-wave teachers referred to these feelings $\left(X^{2}\right.$ $(1, N=88)=.029, p=.865)$. However, negative emotions became more related to teaching ("During online teaching you feel disempowered and helpless."; "I often thought about giving up this activity."), although teachers still referred to their initial reaction to the pandemic ("Nobody was prepared for this."; "In the beginning, I was paralyzed with fear.").

Similar to the first $\left(X^{2}(1, N=85)=1.51, p=.219\right)$ and second wave $\left(X^{2}(1, N=88)=.1 .65, p=.199\right)$, only a few third-wave teachers mentioned negative emotions.

Coping strategies were most often referred to in the first-wave sample $57 \%$ of teachers shared their coping strategies related to the pandemic ("Don't watch the news!"; "Think positive!") and the transition to online teaching ("Just be brave, responsible, and patient."; "Patience, patience, and no panic."). The share significantly dropped in the second-wave sample $\left(X^{2}(1, N=88)\right.$ $=10.33, p=.001)$ to $22 \%$. In parallel, the content of the coping expressions changed - the strategies were less about emotional coping and more about the problems that teachers encountered in their work ("This is just a novelty, which can turn out to be a new experience and give good results."; "Believe in yourself and don't panic.").

The share of the third-wave teachers who wrote about their coping strategies increased slightly, but not significantly in comparison to the second wave $\left(X^{2}(1, N=85)=1.15, p=.285\right)$, and became statistically similar $\left(X^{2}\right.$ $(1, N=85)=3.19, p=.077)$ with the share of the first-wave teachers. In the third wave, teachers focused on overcoming the stress that teaching during the pandemic caused "I would suggest my colleagues lower their expectations and not feel guilty about the outcome."; "We have to remain calm and keep on working.").

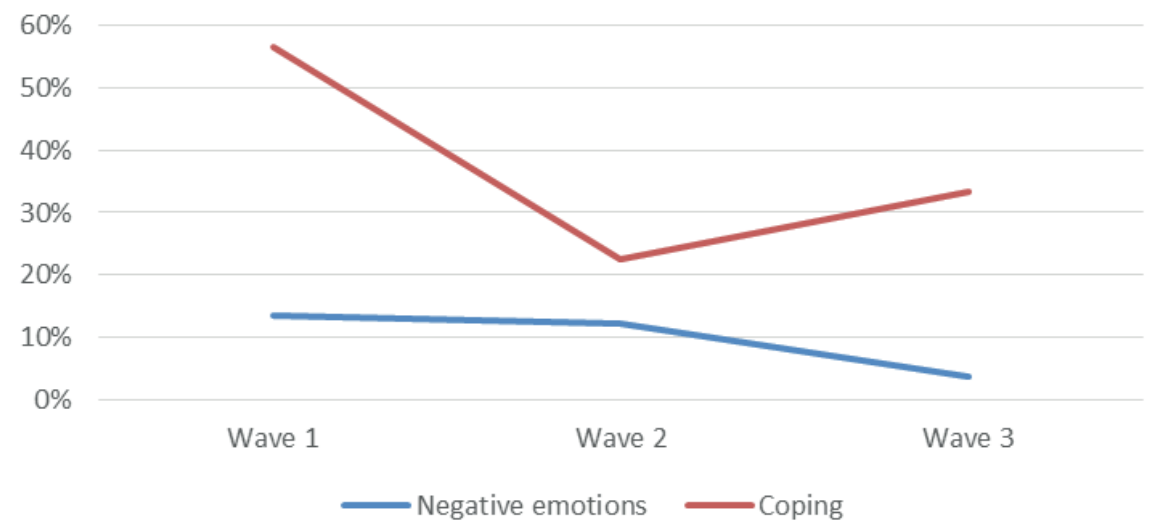

Figure 5. Reflections 


\section{Overall changes in teachers' views}

An overall picture of teachers' responses to the extremely challenging first year of teaching during the pandemic, collected in three waves of sampling, revealed a changing focus of experiences the sampled teachers chose to share in different data collection waves (Figure 6).
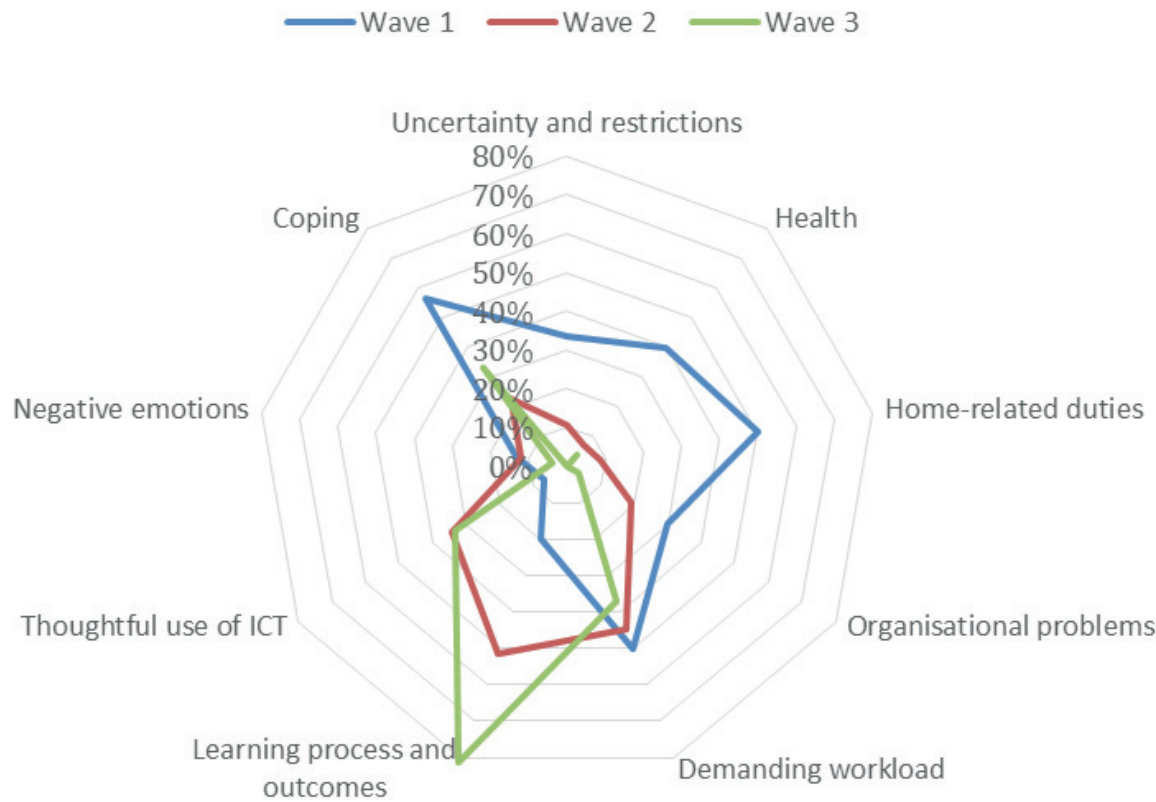

Figure 6. An overview of teachers' narrative values across three waves

The diagram shows distinct differences between the values in focus across the waves, from preoccupation with health, duties, workload, and coping issues in the first wave of sampling, to the new awareness of the learning-process-and-outcomes-related issues in the second wave, to clearly focusing on learning and outcomes, coupled with the teaching-related coping strategies in the third wave of data collection.

As expected, teachers used the two genres in somewhat different ways. Most prominently, coping strategies were expressed in all three waves more often in letters than in stories $\left(X^{2}(1, N=59)=11.27, p=.001 ; X^{2}(1, N=\right.$ $114)=7.03, p=.016 ; X^{2}(1, N=67)=15.40, p=.000$, respectively $)$. Negative emotions, demanding workload, and home-related duties were described more often in stories than in letters in the first wave $\left(X^{2}(1, N=59)=4.75\right.$, $p=.045 ; X^{2}(1, N=59)=7.73, p=.011 ; X^{2}(1, N=59)=11.14, p=.002$, 
respectively), as were uncertainty and restrictions in the second wave $\left(X^{2}(1\right.$, $N=114)=6.33, p=.027)$. However, a more detailed analysis of these intricate time-genre interactions would need to proceed on the coded unit level data and not the binarised ones. Therefore, these will be elaborated elsewhere.

\section{Discussion}

In the narratives written over the first year of the pandemic, teachers shared their experiences of schooling in the changing conditions. Teachers' stories and letters display richness of their expressive stances, bring forward their concerns and emotional reactions to the new challenges, and reveal their coping strategies, alongside the changing roles of their professional and personal life. Our analysis of teachers' narratives captured the dynamic interplay of the expressed values, highlighting the experience of the pandemic, the perception of the schooling situation, and the teachers' reflections about themselves across time and the narrative genre. The dynamic shift of teachers' expressive positioning, from sharing complex concerns with immediate danger, frustration, and pressures, to a focus on educational concern including own coping strategies, is the main finding of this study.

We registered many further nuances of teachers' rich narratives, some also previously highlighted by other studies - implying some universality of teachers' experiences during the pandemic across countries. Our study, however, puts the spotlight on the change and dynamics in the way teachers have positioned themselves across time while grappling with the frightening and unusual context, and highlights the importance of paying sustained attention to the explorations of these experiences. In addition, this multigenre approach provided an opportunity for teachers to convey their reflexive strategies differently, through a letter to a peer rather than through stories, which were reserved more for expressing emotions, contexts, and external actions. A similar trend was found regarding students' use of narrative genres in a related study (Kovács-Cerović et al. 2021) and several others (Daiute, 2021; Daiute \& Kovač-Cerović, 2017), suggesting a clear benefit of the multigenre methodology.

Similar to Kim et al. (2021) and Collie (2021), our study revealed pandemic-induced anxiety and health concerns. Teachers' descriptions of professional duties and colliding roles, as well as their frustration with the newly imposed obligations in their private lives, were similar to the reports of participants in previous studies (e.g., See et al., 2020). However, these concerns were pronounced during the first wave of the study only; with the relaxation of restrictions, other feelings and concerns became salient, more closely related to teachers' professional roles. Studies exclusively focusing on the first wave of reactions would have missed the shift of teachers' focus from the pandemic per se to the teaching and learning requirements. 
Our participants emphasized several school-related problems through four values that showed different dynamics over time. Mentions of organisational issues decreased by the third wave, indicating better overall organisation of education. On the other hand, the concerns with the demanding workload corresponded to those highlighted in other studies (e.g., MacIntyre et al., 2020; Kraft \& Simon, 2020), and remained in teachers' focus on a similar level across all three waves, although with different nuances. A new kind of engagement with students and parents (reported by See et al, 2020), teaching both in-person and online, thus doubling the efforts (also found by Kaden, 2020 and Collie, 2021), and time-consuming preparation of digital teaching resources and setting up platforms (See et al., 2020) were also echoed by our participants as sources of high workload.

Two education-related values had an incremental course over time. Teachers' professional concerns with the learning process and outcomes emerged as salient as their other, more personal concerns diminished and their digital competencies developed, and, from the second wave on, teachers focused on the meaningful use of ICT in teaching. Interestingly, a study involving students (Kovács-Cerović et al., 2021) showed that students, unlike teachers, were more worried about how they would learn and how much they would learn from the very beginning of the pandemic and recognized the importance of creative ICT use even in the first months of online schooling. As for the third major value - reflections on emotions and the management of challenges, teachers' narratives expressed a positive emphasis: they more often stressed coping strategies (both emotion-focused and problemfocused, according to Lazarus \& Folkman, 1984) than describing negative emotions. This was even more pronounced in the first wave, when the circumstances were most stressful, and when more than half of the teachers wrote encouraging words to their colleagues related to the uncertainty of the pandemic. In the later waves, the proportion of teachers sharing coping strategies decreased significantly and the content of both emotion-related and coping-related expressions became more focused on teaching. A similar finding regarding the choice of coping strategies was reported by MacIntyre et al. (2020). Our findings suggest somewhat lower levels of negative emotions than those found by other studies (e.g., Kim \& Ausbry, 2021), probably due to methodological differences, as our respondents could have chosen to express less negative feelings in the narratives.

The study design did not allow for tracing the narration of the same teachers across time. Hence, differences across waves could also stem from sample-specific factors. However, since the three samples were similar in demographic characteristics, the experiences teachers shared across the three waves in the first year of the pandemic provide a solid basis to draw recommendations for policy, practice, and research. 
We highlight the benefits of the methodological approach used. The two narrative genres across time allowed for teachers to express their dynamic stances to the new and changing education reality. Their narratives were full of meaning, reflection, criticism, aspirations to improve the situation, and the examples of their own challenges and coping strategies, which are significant not only for researchers, but for schools and national education authorities as well. They should invite those affected to be heard and improve the policies and measures accordingly.

The study also revealed several key shortcomings in the policies, organisation, and support available in Serbia at the onset of the pandemic already. Timely elimination of these shortcomings could contribute to easier coping with the new situation and improve the effects of learning. Therefore, we urge that institutes, school administrations, publishing houses, pedagogical and teacher education faculties prepare and offer to teachers and schools easily applicable and adjustable high-quality digital contents with all the accompanying materials - instructions, ideas for their use and enrichment, tasks, suitable projects for student engagement and homework, in order to reduce the enormous burden imposed on teachers throughout the pandemic year. The switch to distance learning does not mean "moving" learning from school to home, but transforming curriculum, pedagogy, and assessment; such complex transformation of the main aspects of education should not depend solely on teachers, whose digital skills are certainly limited. The data also point to the extreme importance of good distance-learning organisation, performance monitoring, feedback collection, and making adjustments in accordance with these. Cooperation between students, parents, and teachers was only marginally mentioned in the narratives, signalising a lack of these mechanisms. Purposefully fostering all the potentials for cooperation between different actors and within each group of actors would be therefore highly desirable.

Finally, building teachers' competencies and skills for all aspects of distance education, starting from the initial education of teachers, is essential.

\section{Conclusion}

The current study aimed at exploring the experiences of primary school teachers with COVID-19-related changes of education in Serbia from spring 2020 until spring 2021. The main findings of the study indicate a dynamic change of experiences that teachers expressed at different points of immersion in the pandemic crisis - from addressing broad personal and professional concerns with immediate dangers, frustration, and pressure, towards more professional concerns, focused on educational issues.

Partial agreement with the findings of previous studies shows that some issues are shared across countries, but it also highlights the contribution of an 
integrative, multi-genre approach to encompassing nuanced experiences. The richness of teachers' experiences and their cognate views on the challenges they faced convey important messages to policy-makers as well - to better organise, monitor, support, and guide the emergency distance education so as to release the burden on teachers and ensure better education outcomes.

We would like to close with two remarks for the post-pandemic education.

Education during the pandemic revealed many ruptures and unresolved issues in the education system - analysing them open-mindedly and seeking cooperative solutions could trigger massive post-pandemic education development.

Finally, for the education systems around the world, Serbia included, the first pandemic year was a chance for enormous joint learning and building unexpected competencies in novel areas. These experiences will undoubtedly improve education, generate new modalities, breakthroughs, and novel practices - provided we do not try to act as if this year had never happened, but build on it.

\section{References}

Alarcón López, C., Decuypère, M., Dey, J., Gorur, R., Hamilton, M., Lundahl, C., \& Sundström Sjödin, E. (2021). Dancing with Covid: Choreographing examinations in pandemic times. European Educational Research Journal. https://doi. org/10.1177/14749041211022130

Bakhtin, M. (1986). The problem of speech genres. In C. Emerson \& M. Holquist (Eds.), Speech genres and other late essays (pp. 60-102). University of Texas Press.

Bamberg, M. (2004). Positioning with Davie Hogan: Stories, tellings, and identities. In C. Daiute \& C. Lightfoot (Eds.), Narrative analysis: Studying the development of individuals in society (pp. 135-157). Sage.

Bruner, J. (1987). Life as narrative. Social research, 54(1), 11-32.

Collie, R. J. (2021). COVID-19 and teachers' somatic burden, stress, and emotional exhaustion: Examining the role of principal leadership and workplace buoyancy. AERA Open. https://doi.org/10.1177/2332858420986187

Chiu, T.K.F., Lin, TJ. \& Lonka, K. (2021). Motivating online learning: The Challenges of COVID-19 and Beyond. The Asia-Pacific Education Researcher, 30(3), 187190. https://doi.org/10.1007/s40299-021-00566-w

Daiute, C., \& Nelson, K. (1997). Making sense of the sense-making. Journal of narrative and life history, 7(1-4), 207-215.

Daiute, C. (2008). The rights of children, the rights of nations: Developmental theory and the politics of children's rights. Journal of Social Issues, 64(4), 701-723. https://doi.org/10.1111/j.1540-4560.2008.00585.x.

Daiute, C. (2010). Human development and political violence. Cambridge University Press. Daiute, C. (2013). Narrative inquiry: A dynamic approach. Sage. 
Daiute, C. \& Kovač-Cerović, T. (2017). Minority teachers - Roma in Serbia - Narrate education reform. Belgrade: Institute for Psychology

Daiute, C., Kovács Cerović, T., Mićić, K., Sullu, B., \& Vracar, S. (2020). Dynamic values negotiating geopolitical narratives across a migration system. Qualitative Psychology, 7(3), 367-383. https://doi.org/10. 1037/qup0000166

Daiute, C. (2021). Narrating crisis from war zones to disease zones. Journal of Humanistic Psychology, 61(2), 219-230. https://doi.org/10.1177/0022167820964329.

Frohn, J. (2021). Troubled schools in troubled times: How COVID-19 affects educational inequalities and what measures can be taken. European Educational Research Journal. https://doi.org/10.1177/14749041211020974

Georgakopoulou, A. (2006). Thinking big with small stories in narrative and identity analysis. Narrative inquiry, 16(1), 122-130.

Government of the Republic of Serbia (2020a). Odluka o obustavi izvodenja nastave $u$ visokoškolskim ustanovama, srednjim i osnovnim školama i redovnog rada ustanova predškolskog vaspitanja i obrazovanja. Gazzete of the Republic of Serbia No. $30 / 2020$

Government of the Republic of Serbia (2020b). Uredba o merama za sprečavanje $i$ suzbijanje zarazne bolesti COVID-19. Gazzete of the Republic of Serbia No. $66 / 2020$.

Government of the Republic of Serbia (2020c). Uredba o merama za sprečavanje $i$ suzbijanje zarazne bolesti COVID-19. Gazzete of the Republic of Serbia No. $151 / 2020$.

Government of the Republic of Serbia (2021). Uredba o merama za sprečavanje $i$ suzbijanje zarazne bolesti COVID-19. Gazzete of the Republic of Serbia No. 19/2021.

Jović, S. (2020). "They have been in both positions": Narrative exploration of adolescents' sense-making about injustice from the positions of the object and subject of injustice. Qualitative Psychology, 7(3), 285-305. https://doi.org/10.1037/ qup0000142

Kaden, U. (2020). COVID-19 school closure-related changes to the professional life of a K-12 teacher. Education Sciences, 10(6), 165.

Kara, S. B. K., Günes, D. Z., \& Tüysüzer, B. S. (2021). Work-Family conflict during working from home due to pandemic: A qualitative research on female teachers. International Journal of Curriculum and Instruction, 13(1), 251-273.

Kim, L. E., Leary, R., \& Asbury, K. (2021). Teachers' narratives during COVID-19 partial school reopenings: an exploratory study. Educational Research, 1-17. https://doi.org/10.1080/00131881.2021.1918014

Kovács Cerović, T., Mićić, K., \& Vračar, S. (2021). A leap to the digital era-what are lower and upper secondary school students' experiences of distance education during the COVID-19 pandemic in Serbia? European journal of psychology of education. https://doi.org/10.1007/s10212-021-00556-y

Kraft, M. A., \& Simon, N. S. (2020). Teachers' experiences working from home during the COVID-19 pandemic. Upbeat. Downloaded July, 7, 2020.

Lazarus, R. S. (2006). Emotions and interpersonal relationships: Toward a personcentered conceptualization of emotions and coping. Journal of personality, 74(1), 9-46. https://doi.org/10.1111/j.1467-6494.2005.00368.x 
Lazarus, R. S., \& Folkman, S. (1984). Stress, appraisal, and coping. Springer publishing company.

Lepp, L., Aaviku, T., Leijen, Ä., Pedaste, M., \& Saks, K. (2021). Teaching during COVID-19: The decisions made in teaching. Education Sciences, 11(2), 47. https://doi.org/10.3390/educsci11020047

MacIntyre, P. D., Gregersen, T., \& Mercer, S. (2020). Language teachers' coping strategies during the Covid-19 conversion to online teaching: Correlations with stress, wellbeing and negative emotions. System, 94. 10.1016/j.system.2020.102352

McFarlane, A. E. (2019). "Devices and desires: Competing visions of a good education in the digital age." British Journal of Educational Technology, 50(3), 11251136. https://doi.org/10.1111/bjet.12764

Niemi, H. M., \& Kousa, P. (2020). A case study of students' and teachers' perceptions in a Finnish high school during the COVID pandemic. International Journal of Technology in Education and Science, 4(4), 352-369. https://doi.org/10.46328/ ijtes.v4i4.167.

Parker, I. (2004). Qualitative Psychology: Introducing radical research. McGraw-Hill Education.

Patton, M. Q. (2002). Qualitative research and evaluation methods (3rd ed.). Sage.

Pelikan, E. R., Lüftenegger, M., Holzer, J., Korlat, S., Spiel, C., \& Schober, B. (2021). Learning during COVID-19: The role of self-regulated learning, motivation, and procrastination for perceived competence. Zeitschrift für Erziehungswissenschaft, 24(2), 393-418. https://doi.org/10.1007/s11618-021-01002-x

See, B. H., Wardle, L., \& Collie, P. (2020). Teachers' wellbeing and workload during Covid-19 lockdown. Durham University Evidence Centre for Education and Schoolzone.

Tabor, L., \& Smith, P. (2020). End of the Field? Hacking Online and Hybrid Environments for Field-Based Learning in Geography Education. Journal of Geography, 120(1), 3-11. https://doi.org/10.1080/00221341.2020.1858325

Toquero, C. M. D. (2020). Emergency remote teaching amid COVID-19: The turning point. Asian Journal of Distance Education, 15(1), 185-188. https://doi. org/10.5281/zenodo.3881748

Wicaksana, E. J., Atmadja, P., Wikanso, W., Putri, L. N., \& Muthia, G. A. (2020). Edmodo as a solution to enhance student learning interest in high school biodiversity during the COVID-19 pandemic. Biosfer: Jurnal Pendidikan Biologi, 13(2), 216-229. https://doi.org/10.21009/biosferjpb.v13n2.216-229 


\section{Trendovi u iskustvima nastavnika osnovnih škola tokom prve godine COVID-19 pandemije u Srbiji: analiza narativa}

\section{Katarina Mićić 5}

Odeljenje za psihologiju, Filozofski fakultet, Univerzitet u Beogradu

\section{Tünde Kovács Cerović}

Odeljenje za psihologiju, Filozofski fakultet, Univerzitet u Beogradu

\section{Selena Vračar}

Odeljenje za psihologiju, Filozofski fakultet, Univerzitet u Beogradu

Apstrakt: Cilj ovog istraživanja je sagledavanje iskustava osnovnoškolskih nastavnika o obrazovanju tokom COVID 19 pandemije. Nastavnički narativi o ovim iskustvima prikupljeni su u tri navrata, pomoću onlajn instrumenta. Ukupno 116 ispitanika je napisalo 233 narativa u obliku priče i pisma. Na narativima je primenjena analiza vrednosti i dobijeni podaci su podvrgnuti dodatnim statističkim analizama, te su se vrednosti koje su nastavnici iskazali uporedili kroz tri ključne faze organizovanja obrazovanja u Srbiji tokom prve godine pandemije. Sveukupno, identifikovane su tri nadređene vrednosti i devet užih vrednosti. Multižanrovski i višetalasni pristup koji je primenjen u ovom istraživanju omogućio je dobijanje nijansirane i sveobuhvatne slike najvažnijih nastavničkih utisaka, briga i strategija u novoj realnosti, kao i uvid u dinamične promene naglasaka u narativima nastavnika tokom prve godine pandemije. Nastavnici koji su učestvovali u prvom talasu istraživanja najviše su se fokusirali na zdravlje i prevenciju, na svoje porodične obaveze, opterećenje poslom i na koping strategije. U drugom talasu, kada se opasnost smanjila, nastavnici pokazuju povećanu usmerenost na probleme u nastavi. Nastavnički narativi u trećem talasu najveći fokus stavljaju na proces i ishode učenja. $\mathrm{Na}$ osnovu sprovedenih analiza, date su preporuke za obrazovne politike.

Ključne reči: COVID-19, obrazovanje na daljinu, nastavnici, analiza vrednosti, dinamičko pripovedanje 